\title{
Constraints of Teacher in The Process of Learning Geography Blind Students in SLB Bandar Lampung
}

\author{
Dian Utami ${ }^{1}$, Annisa Salsabilla ${ }^{2}$ \\ \{dian.utami@fkip.unila.ac.id ${ }^{1}$, annisa.salsabilla@fkip.unila.ac.id ${ }^{2}$ \} \\ Universitas Lampung, Pendidikan Geografi ${ }^{1}$
}

\begin{abstract}
This study aims to determine what obstacles are faced by teachers on implementing geography learning process for blind students in Bandarlampung and how to overcome these problems. The research was conducted at SLB Bina Insan Bandarlampung. The subjects in this study were teachers who taught geography. The method is descriptive qualitative. It is used to describe the obstacles faced by the teacher. The data was carried out through in-depth interviews, to obtain accurate information about the obstacles and what the efforts made to solve this problem. The results showed that there are several obstacles, i.e teachers have difficulty translating basic competency into several material indicators, difficulty choosing effective learning methods and strategies, difficulty making assessment instruments, lack of media, time in delivering material, and understanding the braille. The teacher's efforts are using tactile maps in learning, placing adjustment, hardening the voice, and using teaching methods.
\end{abstract}

Keywords: Blind students, geograpgy learning, teacher constraint

\section{Introduction}

In general, there are already articles that examine the problem of implementing learning in blind students in several subject areas [1],[2], but there is no article that examines the rigor of learning geography for blind students. Given the importance of geography as a subject that must be followes by students.

This research was made to examine what is related to the teacher in implementing learning for blind students. It is very important to see from this site so teachers can make appropriate efforts in implementing geography learning for blind students so that learning can be carried out effectively and efficiently.

In accordance, all human beings have various needs, invariably children with special needs. One of the fundamental needs is education. By providing education to children with special needs are expected to have the ability and skills for their survival so that it does not always depend on the help of others. The place for children with special needs in educational institutions means that some of their needs in getting an education. Through education, children with special needs are expected to be able to expand their horizons of life. So that children with special needs can think creatively, innovatively, and productively. Thus, children with special needs can compete and get the same rights in the job field. Blindness is a shortcoming of a visually impaired person, limiting the opportunities that the visually impaired have to get a fair education and career path. Even blind student still have the opportunity to get the same right as a normal student [3]. 
In 2012, data from the Directorate of Special Education and Special Services of the Ministry of Education stated that in 2012, the number of children with special needs in Indonesia recorded reached, 1,544,184 children. Only 85,737 children $(25.92 \%)$ received formal education services, either in special schools (SLB) or inclusive schools. "That is, there are still 245,027 children with special needs $(74.08 \%)$ who have not received education in school [4].

The term special needs are explicitly addressed to children who are considered to have abnormalities/deviations from the average normal child's condition generally, in terms of physical, mental, and social behavior characteristics [5]. It can be concluded that the understanding of the blind is an individual who has suffered vision damage in such a way that he cannot use his sense of vision for educational or other purposes even though he has been helped by tools, so he needs special educational assistance or services.

Children with visual impairment can be known to be in the condition: (a). The sharpness of their vision is less than the sharpness that the normal children. (b). There is a noise in the lens of the eye or there is a certain liquid. (c). The position of the eye is difficult to control by the nerves of the brain. (d). There is damage to the nervous structure of the brain associated with vision[6]. Those who are categorized as children with physical needs include abnormalities in the visual senses (visually impaired) hearing sensory abnormalities (deaf) impaired speech (speech impaired) and impaired functioning of the limbs (physically disabled). A visually impaired child is a child who because of something experiences has a vision condition that does not work properly. The condition is caused by eye damage, optic nerve or part of the brain can't process visual stimulus. Based on preliminary research conducted by the authors, data on the condition of the grade 9th blind students at SLB A Bina Insani Bandar Lampung is presented in Table 1.

Table 1. Condition of Blind Students

\begin{tabular}{llll}
\hline No of Respondent & Gender & Causative factor & Description \\
\hline 1 & Male & Birth blind & Total visually impaired \\
2 & Female & Birth blind & Total visually impaired \\
3 & Male & Birth blind & Total visually impaired \\
4 & Female & Glaucoma & Total visually impaired \\
5 & Male & Glaucoma & Partially visually impaired (low vision) \\
6 & Male & Glaucoma & Partially visually impaired (low vision) \\
\hline
\end{tabular}

Based on table 1, student of XI grade at SLB A Bina Insani Bandar Lampung consists of 6 students with different blindness condition. The condition will also affect the ability of visually impaired students to understand learning. Blindness can make a limitation for children on their activity including for obtaining information. As stated by experts that approximately $85 \%$ of human observations are carried out by the eye [7]. This was conveyed by Utami [8], the limitations of visual/visual stimuli, causing visually impaired children to be less able to orient to their environment so that their mobility skills were impaired. The nature of dependence on others may occur in the visually impaired. This may be because they have not tried their best to overcome their difficulties so always expect the help of others.

Children with visual impairment can be known in the condition: (1) The sharpness of their vision is less than the sharpness that the alert person has. (2) There is a noise in the lens of the eye or there is a certain liquid. (3) The position of the eye is difficult to control by the nerves of the brain. (4) There is damage to the nervous structure of the brain related to vision [6]. The Government of Indonesia itself strives to facilitate the educational needs for special needs with 
the establishment of extraordinary schools that have been spread throughout Indonesia. In its implementation, it is undeniable that teachers often experience problems in learning and need strategies in learning. Certainly in contrast to the constraints experienced by special education teachers. Special education teachers should have knowledge of children with special needs, patience, and good physical and mental health.

Learning for visually impaired children needs to pay attention to the following principles; (1) Individual Principles; This individual principle is a general principle in the implementation of learning in both context of special education and public education. Teachers are required to pay attention to individual differences students, (2) The Principles of Real Object (Sensing Experience); The learning strategy used by teachers should allow blind children to gain real experience of what they learn. This is also referred to as the "direct sensing experience, (3) The Principle of Totality; Learning strategy by teachers that enables students to gain a complete experience of objects and situations can occur if the teacher encourages students to engage all of their sensing experiences in an integrated way of understanding a concept, (4) The Principle of Self-Learning; Activities for visually impaired children should enable or encourage the child to learn actively and independently. Children learn to search and discover, while teachers are facilitators that help make it easier for students to learn and motivators that evoke their desire to learn.

Geography learning is one of the important and fundamental areas of study taught in both primary and secondary schools. This is because geography covers where humans live as well as the phenomena that occur. Any field of knowledge that a person learns always begins with observations on the face of the earth so geography is said to be the mother of science. Geography as a field of science has an explanation of a character as a result of the interaction of geographic factors that characterize the places on the surface of the earth as human dwellings, including the utilization of natural resources and the environment for the benefit of life. Geography has the object of earth's surface study with a relationship of space, so it has a strong position in providing knowledge to a set of people in studying various aspects of life on earth. The description of materials and subjects needs to be adapted to the child's abilities, age, methods, and mental development. This is so that the material in the material can be easily accepted.

Nursid [9] stated that geography learning is essentially a study of aspects of the earth's surface that are the overall symptoms of nature and human life with regional variance. Therefore geography learning in schools is a study of the nature of geography that includes aspects of space, environment, and spatial. The object of geography study is a geosphere consist of an atmosphere, lithosphere, hydrosphere, and biosphere that is adjusted to the level of psychological development of students at the educational levels.

Based on Permendiknas number 22, 2006 [10] on the standard of content, the geography learning in the school aims to have students that have the ability (1) spatial, environmental, and territorial patterns and related processes, (2) master basic skills in obtaining data and information, communicating and applying geographic knowledge, (3) display caring behavior towards the environment and utilizing natural resources wisely and have a tolerance to the cultural diversity of society [6].

Learning is a process organized by teachers and taught students in learning how to acquire and process knowledge, skills, and attitudes [11]. But every profession must have its problems, including teachers. In the Great Dictionary of Indonesian Language, obstacles are an obstacle; obstacles; Constraints. Teacher constraints are obstacles or obstacles experienced by someone who is a teacher. In this case, the obstacles that will be reviewed are the constraints that occur in the learning process. Obstacles in learning are some of the obstacles that hinder the course of 
learning seen from human factors (teachers and learners), institutional factors (classrooms), and instructional (lack of props) [12].

There need to be adjustments to a person with visual impairment or a visually impaired child who has its peculiarities and ways to achieve the same stage in its development, including in the field of education. In treating and serving children low vision is to use teaching principles namely lighting, color contrast, font size, time, teaching methods that have been specifically designed in learning [13].

For geography subjects of SLB A Bina Insani, students are taught by a geography graduate teacher, but the teacher has never attended an additional competency course to strengthen the competency of educating children with special needs. This becomes an obstacle for geography teachers in delivering learning effectively to students. while teachers are supposed to be good facilitators in the learning of visually impaired students.

\section{Method}

The research method used in this study is a descriptive qualitative method. Qualitative descriptive aims to describe phenomena as they are, more characteristics, quality of interconnectedness between activities [14]. The qualitative descriptive research method used in this study aims to illustrate the constraints that teachers face in carrying out the process of geography learning.

The subject in this study was geography teacher class XI at SLB A Bina Insani Bandar Lampung School Year 2019/2020, while the object of this research was the teacher constraints that teachers faced in carrying out the geography learning process in Blind Students, Grade XI at SLB A Bina Insani Bandar Lampung.

The researcher chose the school because the teacher who taught geography was a graduate of geography education who had never received any training and knowledge about how to teach students with special needs with visual impairments. Also, research locations that are close and easily accessible are a consideration in determining the research location.

Research data collection was carried out through in-depth interviews, namely through the process of obtaining information for research purposes through face-to-face question and answer between the interviewer and the respondent, with or without using interview guidelines where the interviewer and informant are involved in a relatively long social life.

This interview was conducted to get accurate information about the obstacles faced by teachers as well as efforts made in carrying out the process of geography learning in Blind Students Grade XI at SLB A Bina Insani Bandar Lampung. The data analysis technique used in this study is a descriptive data analysis technique, without using the statistical formulas. 


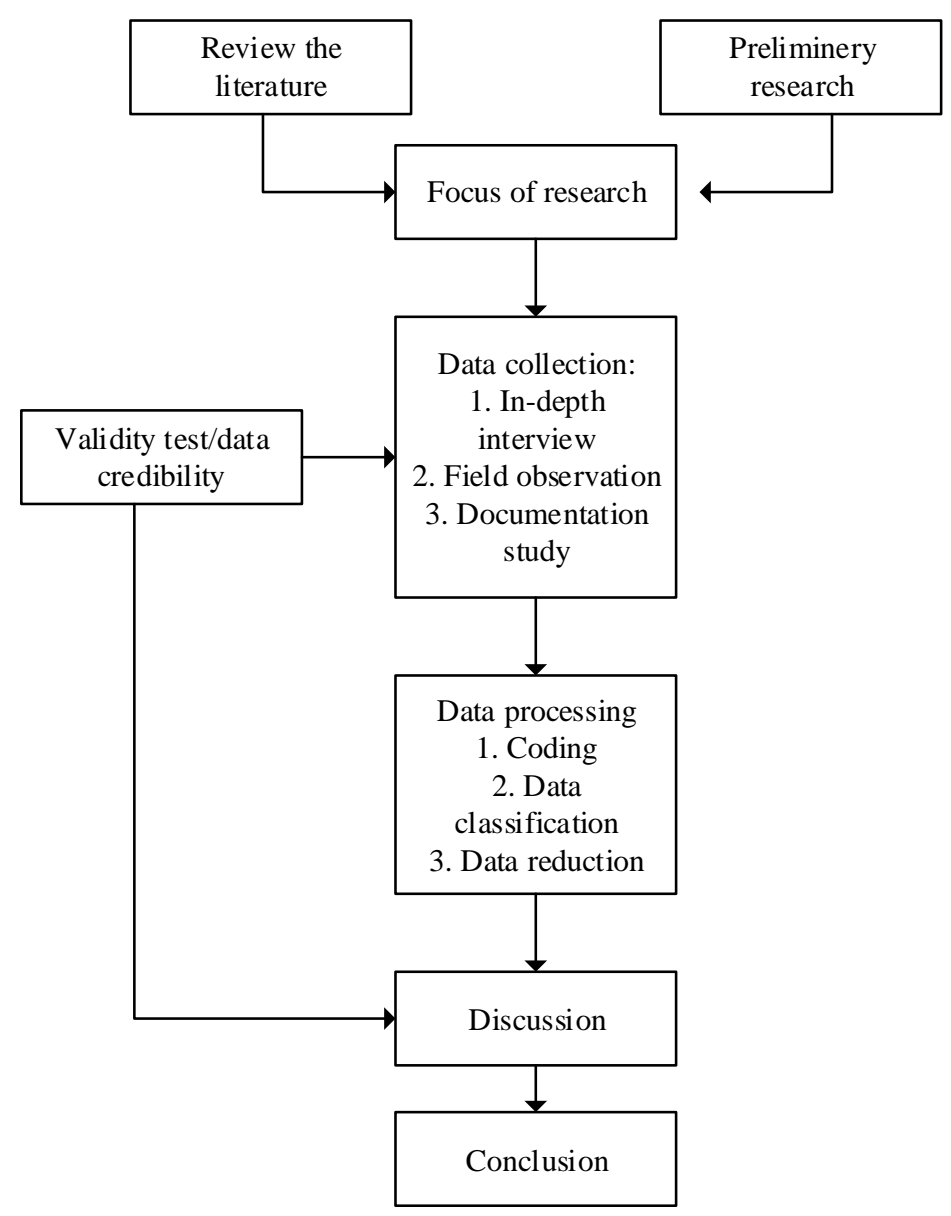

Fig. 1. Research flow chart

\section{Result and Discussions}

\subsection{Teacher Constraints}

Education is one of the government programs that must be implemented to achieve the goals that have been announced. Educating children with physical, mental, or social behavioral characteristics is not the same as educating a normal child, because in addition to requiring a special approach also requires strategy and special learning tools. There are important obstacles in the learning process of students, for example, the lack of special materials and equipment for the visually impaired [15]. This is sole because it relies on the condition experienced by different children. Therefore, based on observations and interviews of researchers with teachers who teach geography subjects are informed that the number of students of SLB A Bina Insani as many as 6 people and there are some obstacles faced during the study. 
Teachers have difficulty describing KD into several material indicators. The syllabus used is the syllabus created by the government. There is no specific difference in the syllabus for SLB and public schools. The syllabus contains core competencies. The core competency is then passed down in the basic competence as well as indicators. In this case, teachers are required to be able to lower KI and KD into appropriate learning indicators, judging by KI and KD which are then adapted to the student code. The achievement of the level of thinking made by teachers should be simpler so that students can achieve learning indicators with limited conditions without any difficulties.

Difficulty choosing effective learning methods and strategies. Based on the results of the study, the purpose of geography learning formulated by SLB A Bina Insani is somewhat different from other schools. It is adapted to different child conditions with the child in general. The level of thinking set is slightly lower. But for the material, the researchers found no material difference between SLB A Bina Insani and public schools. This makes teachers work harder in learning so that students can achieve established learning indicators and objectives. Teachers find it difficult to determine effective strategies due to the teacher's lack of experience in dealing with special needs students. Teachers have never undergone training in the face of special needs students in the classroom. It is also suggested by previous research, that teachers complain of a lack of competence in handling special needs students, this is due to the lack of understanding of teachers about special needs students which then impacts the problems that arise. Furthermore, teachers have difficulty in teaching and learning activities. Also supported by the fact that teachers who have an inappropriate educational background [16].

Lack of Media. With the implementation of learning for visually impaired students, there are no media specifically reserved for special needs students. The media used when the teacher explains is the same as other students. Only tactual maps have schools as a medium of geography learning. Teachers have difficulty finding suitable media to convey abstract and concrete concepts, for example when explaining about seabed morphology, mining, food security, and others. In general, geography teachers only use video to support learning.

Teachers have difficulty making assessment instruments. The learning evaluation standard for the special needs children follows the Minimum Completed Criteria set by the school of 70 . The evaluation question given to the Special needs is adjusted to the indicator stimulated by the school. Based on interviews with geography teachers, teachers have difficulty developing process assessment instruments and learning outcomes that include cognitive, affective, and psychomotor performance.

Lack of Time in Delivering Materials. The teacher is unable to convey all the material contained in the book because there is not enough time to explain the entire material. The ability between visually impaired students and normal learners is certainly different, explaining material to SPECIAL NEEDS students take more time for the material to be conveyed clearly. Besides, blind learners also need more time in understanding the subject matter. Moreover, books used in learning are not books specifically for visually impaired students and the media available is less. All children, including visually impaired children, have developed potential, although, in reading and writing learning, blind children sometimes have to take a bit longer compared to children in general. This is due to the limitations experienced by them. Therefore, a blind child teacher is also required to be patient, conscientious, and creative, and willing to be a substitute for the eyes of visually impaired students [17]. 
Teachers Lack Understanding Of Braille. Braille is used by visually impaired students for studying the subject matter. Reading and writing Braille is one of the tools for people with blind visual disabilities to obtain information and communicate with others who use tactile nerve. Thus the sensitivity of tactile nerve is a demand in having braille reading and writing proficiency. Geography teachers, meanwhile, lack using the braille media. This certainly inhibits learning, because braille is the only letter that can be mastered by visually impaired students. This lack of understanding leads to constraints in the learning process and evaluation. The lack of understanding of Braille by teachers is because teachers have never participated in training for learning Braille and practice it. This was also conveyed by Dwi [18]. Another obstacle faced by the classroom teacher is the limitations of the classroom teacher about reading brailed and mobility orientation so the classroom teacher has not been able to guide the child to the maximum

\subsection{Teacher's Efforts to Overcome Obstacles}

Use of Taktual Maps. Based on the results of interviews and observations of geography teachers always use tactual maps in geography learning. For example, materials that can use tactual maps are the spread of flora and fauna, the spread of mining goods and other materials. The use of tactual maps as a medium can be more easily understood by visually impaired students through the senses of touch so that students can imagine the face of the earth. Tactical maps produce an accessible means of touch (tactual) to know the distribution and relationship of various geographic phenomena and effectively to transmit room information to the visually impaired, thus benefiting in unhelpful mobility, as well as for the increasing use of the relationship of a phenomenon that is still abstract. Tactual maps have a Tactile sensation that is a sensation that is felt when the skin experiences direct contact with objects (such as vibration, pulse, pressure, temperature, size, shape, texture, direction, and height), used to recognize space [19].

The potential of the visual blind in this tactile sensation brings up to a tactual perception that is realized using tactual variables in tactual mapping to distinguish the elements represented on each symbol on the map. The goal is to elicit a specific mental or thought response after being poisoned.

Place Adjustment Principles. In addition to interviews, the researchers observed that the principle was applied by geography teachers. The principle is used in learning by placing the SPECIAL NEEDS in a position close to the board and teachers so that the SPECIAL NEEDS can be helped a little while reading the writing on the board and hear the teacher's voice. Visually impaired students rely entirely on visual learning, they are easier to capture material by sharpening hearing.

Hardening Principles. Based on the observation of the use of the principle has been applied by geography teachers in learning. The teacher speaks his voice at maximum volume at the time of the material member and writes on the board. This is very helpful for visually impaired students because clear sounds will be able to be captured through the listener's senses.

Principles of Use of Teaching Methods. Based on interviews on the principle of using varied methods during learning to grade XI SLB students. Geography teachers often apply discussion methods, Q\&A, and lectures to help students understand the materials they have been taught. 
This is a form of use of varied methods given by teachers so that students do not feel bored. Only such methods are considered effective in delivering geography subject matter to ABL students. The implementation of learning activities is the main thing and determinant of the running of professionalism of a teacher in teaching. A teacher is not only charged with preparing materials but must also be prepared in all things, namely being able to make learning conditions more alive, not boring, on the other hand, students are also better prepared and should not let any lessons slip[20].

\section{Conclusion}

Based on the results, there are several obstacles faced by teachers in implementing geography learning for blind students at SLB A Bina Insani. Teachers have difficulty translating basic competence into several material indicators, difficulty choosing effective learning methods and strategies, and making assessment instruments, lack of media, lack of time in delivering material, and teachers do not understand the braille.

When associated with the existing theory, constraints in learning are some obstacles that hinder the course of learning as seen from human factors (teachers and students), then the factors that become obstacles for teachers in implementing geography learning for blind students at SLB A Bina Insani Bandarlampung are constrained by human factors (teachers and students) and instructional (lack of teaching aids). For the efforts made by the teacher, namely by treating and serving low vision children using teaching.

Acknowledgments. Thank you for LPPM Universitas Lampung as a sponsor for this research.

\section{References}

[1] M. J. Shodiq, "Problematika Pembelajaran Bahasa Arab bagi Mahasiswa Tunanetra di Fakultas Ilmu Tarbiyah dan Keguruan UIN Sunan Kalijaga,” J. C., vol. VII, no. 2, pp. 163-174, 2014.

[2] D. R. Saputri, "Proses Pembelajaran Seni Musik bagi Siswa Tunanetra," Harmon. - J. Pengetah. dan Pemikir. Seni, vol. 13, no. 1, pp. 37-44, 2013.

[3] C. Carpio, M. Amérigo, and M. Durán, "Study of an inclusive intervention programme in pictorial perception with blind and sighted students," Eur. J. Spec. Needs Educ., vol. 32, no. 4, pp. 525-542, Oct. 2017.

[4] T. Handayani, D. Angga, and S. Rahadian, "Peraturan perundangan dan implementasi pendidikan inklusif,” Masy. Indones., vol. 39, no. 1, pp. 27-48, 2013.

[5] M. Efendi, Pengantar Psikopedagogik Anak Berkelainan. Jakarta: Bumi Aksara, 2006.

[6] Surya Dharma, "Modul Guru Pembelajar SLB Tunanetra : Kelompok Kompetensi B.” p. 2016, 2008.

[7] F. H. Sasraningrat, "Metode Khusus Tunanetra," Yogyakarta Fed. Kesejaht. Tunanetra Indones., 1981.

[8] A. Utami and P. Suriyah, "Strategi Guru Dalam Membelajarkan Matematika Terkait Pengetahuan Konseptual Kepada Anak Tunanetra,” J. Deriv., vol. 2, no. 1, pp. 11-23, 2015.

[9] N. Sumaatmadja, Metodologi pengajaran geografi. Jakarta: Bumi Aksara, 1997.

[10] P. N. 22 T. 2006, "Permendiknas No 22 Tahun 2006 tentang standar isi," 22. 
Departemen Pendidikan Nasional, Jakarta, 2006.

[11] M. Dimyati, "Belajar dan pembelajaran," Jakarta: Rineka Cipta, 2006.

[12] O. Hamalik, Perencanaan pengajaran berdasarkan pendekatan sistem. Bumi Aksara, 2003.

[13] A. Widdjajantin and I. Hitipeuw, Ortopedagogik Tunanetra I. Jakarta: Departemen Pendidikan dan Kebudayaan, 1996.

[14] N. Sudjana, Penilaian Hasil Belajar Mengajar. Bandung: Remaja Rosdakarya, 2009.

[15] F. Tavares and Clarisse Nunes, "The inclusion of Blind Students in Primary Schools in Praia: Teacher's opinion," in Proceedings of Braga 2014 Embracing Inclusive Approaches for Children and Youth with Special Education Needs Conference, 2014, pp. 736-740.

[16] Nissa Tarnoto, "Permasalahan - Permasalahan yang Dihadapi Sekolah Penyelenggara Pendidikan Inklusi pada Tingkat SD,” J. Humanit., vol. 13, no. 1, pp. 50-61, 2019.

[17] S. Rudiyati and U. N. Yogyakarta, "Pembelajaran Membaca dan Menulis Braille Permulaan pada Anak Tunanetra," Jassi Anakku, vol. 9, no. 1, pp. 57-65, 2010.

[18] D. Y. F. Putri, "Proses Pembelajaran Pada Sekolah Dasar Inklusi.," Ilm. Pendidik. khusus, vol. 1, no. September, pp. 168-179, 2012.

[19] A. L. Griffin, "Feeling it out: the use of haptic visualization for exploratory geographic analysis," Cartogr. Perspect., no. 39, pp. 12-29, 2001.

[20] M. Maftuhin and A. J. Fuad, "Pembelajaran Pendidikan Agama Islam Pada Anak Berkebutuhan Khusus,” J. An-Nafs Kaji. Penelit. Psikol., vol. 3, no. 1, pp. 76-90, 2018. 